\title{
EFEKTIVITAS PROGRAM KARTU JAKARTA PINTAR DI SMK N 19 JAKARTA
}

\author{
Anna Yuliana Antika Sari ${ }^{1}$ dan Adeng Hudaya ${ }^{2}$ \\ ${ }^{1}$ Mahasiswa Program Studi Pendidikan Ekonomi Universitas Indraprasta PGRI \\ ${ }^{2}$ Dosen Program Studi Pendidikan Ekonomi Universitas Indraprasta PGRI \\ Email : anna_janty@yahoo.co.id
}

\begin{abstract}
Abstrak
Tujuan dari penelitian ini adalah untuk mengetahui sejauhmana efektivitas program Kartu Jakarta Pintar di SMK N 19 Jakarta. Jenis penelitian yang penulis gunakan dalam penelitian ini adalah kualitatif deskriptif. Sampel yang digunakan dalam penelitian ini adalah seluh siswa yang mendapatkan Kartu Jakarta Pintar yaitu sebanyak 50 siswa. Hasil penelitian menunjukan bahwa pelaksanaan Program Kartu Jakarta Pintar di SMK N 19 Jakarta berjalan efektif, meskipun pada indikator penggunaan dana yaitu penggunaan KJP untuk transportasi dan pemanfaatan program ekstrakulikuler masih rendah, yaitu $54 \%$ dan $4 \%$.
\end{abstract}

Kata Kunci : Efektivitas, Kartu Jakarta Pintar

\section{PENDAHULUAN}

Pendidikan adalah bagian dari upaya untuk memampukan setiap insan dalam mengembangkan potensi dirinya agar tumbuh menjadi manusia yang tangguh dan berkarakter serta berkehidupan sosial yang sehat. Kualitas pendidikan yang baik sangat diharapkan dalam membangun sumber daya manusia yang berkualitas dan berdedikasi tinggi terhadap negara. Pendidikan yang berkualitas ini diharapkan mampu menjadi sarana proses transmisi ilmu pengetahuan, keyakinan, nilai-nilai, ketrampilan dan aspek-aspek lainnya dari generasi ke generasi. Sistem penyelanggaraan pendidikan yang meliputi kejelasan arah kebijakan yang ditetapkan menjadi faktor penting dalam meningkatkan kualitas pendidikan itu sendiri.Kebijakan Pendidikan di Indonesia mendasarkan pada pasal 31 UUD 1945 yang mengamanatkan bahwa tiap-tiap warga berhak mendapatkan pengajaran, pemerintah mengusahakan dan menyelenggarakan satu sistem pengajaran nasional.

Sesuai dengan Undang-undang Nomor 20 tahun 2003 tentang sistem pendidikan nasional yaitu pendidikan nasional berfungsi mengembangkan kemampuan dan membentuk watak serta peradaban bangsa yang bermanfaat dalam rangka mencerdaskan kehidupan bangsa, bertujuan untuk berkembangnya potensi peserta didik agar menjadi manusia yang beriman dan bertakwa kepada Tuhan Yang Maha Esa, berakhlak mulia, sehat, berilmu, cakap, kreatif, mandiri, dan menjadi warga negara yang demokratis serta bertanggung jawab, yang kemudian menjadiarah kebijakan dalam 
dunia pendidikan. Arah kebijakan pendidikan ini kemudian didukung dengan UU Nomor 32 tahun 2004 tentang Pemerintah Daerah,dimana dalam bagian ketentuan umum pasal 1 ayat 5 dikatakan bahwa "Otonomi daerah adalah hak, wewenang, dan kewajiban daerah otonom untuk mengatur dan mengurus sendiri urusan pemerintahan masyarakat setempat sesuai dengan peraturan perundang-undangan. Makna dari undang-undang ini adalah dimana adanya desentralisasi atau pelimpahan wewenang dari pemerintah pusat terhadap pemerintah daerah untuk mengatur dan mengurus urusan pemerintahan dalam system Negara Kesatuan Republik Indonesia dimana salah satunya adalah desentralisasi pendidikan.

Salah satu aspek penting dalam pembangunan pendidikan adalah pembiayaan. Masalah pokok dalam pembiayaan pendidikan adalah bagaimana mencukupi kebutuhan operasional disatu sisi, dan sisi lain bagaimana melindungi masyarakat (khususnya keluarga tidak mampu) dari hambatan biaya untuk memperoleh pendidikan. Pembiayaan pendidikan pada dasarnya merupakan proses alokasi sumber-sumber pada kegiatan-kegiatan atau program-program pelaksanaan operasional pendidikan atau dalam proses belajar mengajar (Matin, 2014 : 4). Hal-hal yang berkaitan dengan ini meliputi perencanaan anggaran pendidikan, pembiayaan pendidikan, pelaksanaan anggaran pendididkan, akuntansi pertanggungjawaban keuangan pendidikan serta pemeriksaan dan pengawasan anggaran pendidikan.

Provinsi DKI Jakarta adalah ibu kota Negara, yang juga merupakan pusat pemerintahan, pusat perekonomian, dan sebagai daerah otonom. Selayaknya ibu kota Negara pada umumnya, tak jarang DKI Jakarta dijadikan percontohan daerah otonom yang lain termasuk dalam hal kebijakan yang dikeluarkan dalam dunia pendidikan. Jenis masyarakat yang heterogen ini membuat DKI Jakarta dihadapkan pada persoalan yang multikarakteristik. Teknologi, budaya, kemampuan bahkan selera yang beragam ini membuat DKI Jakarta harus menjalankan beberapa kebijakan yang sekiranya sesuai dengan kebutuhan masyarakatnya.

Program Kartu Jakarta Pintar yang selanjutnya disingkat KJP ini merupakan salah satu kebijakan yang kemudian dikeluarkan oleh Pemerintah DKI Jakarta dalam rangka pemenuhan besaran Dana Sumbangan Pendidikan (DSP). Dilansir dari situs resmi KJP (kjp.jakarta.go.id), besaran dana rutin KJP yang dapat digunakan untuk bertransaksi di mesin EDC untuk tingkat SD/MI/SDLB adalah sebesar Rp. 100.000, 
untuk tingkat SMP/MTs/SMPLB Rp. 150.000,untuk SMA/MA/SMALB adalah sebesar Rp. 200.000. Dana ini hanya bisa dibelanjakan setelah tanggal 10 setiap bulannya.

Sesuai dengan Peraturan Gubernur (Pergub) DKI Jakarta Nomor 174 tahun 2015 mengenai Bantuan Biaya Personal Pendidikan (BBPP) Bagi Peserta didik Dari Keluarga Tidak Mampu melalui program Kartu Jakarta Pintar, sasaran penerima bantuan ini adalah peserta didik dari keluarga tidak mampu yang berdomisili dan bersekolah di DKI Jakarta. Keluarga tidak mampu yang dimaksud adalah keluarga yang sangat miskin, miskin, hampir miskin, dan rentan miskin sesuai dengan kriteria Pendataan Program Perlindungan Sosial (PPLS) dan Badan Pusat Statsistik dan/atau berdasarkan fakta sosial dan ekonomi yang ditemukan secara nyata di masyarakat.

Adapun tujuan program KJP dikutip dari situs resminya (kjp.jakarta.go.id) yaitu untuk mendukung terselenggaranya program wajib belajar 12 tahun, mendukung akses layanan pendidikan secara adil dan merata, menjamin kepastian mendapatkan layanan pendidikan dan meningkatkan kualitas hasil pendidikan. Dalam hal ini pemerintah DKI Jakarta menunjuk Bank DKI sebagai sarana penyaluran dana KJP kepada peserta didik dalam bentuk kartu ATM.

Lazimnya sebuah kebijakan, KJP juga tidak lepas dari persoalan-persoalan untuk mencapai tujuannya.Dalam beberapa pemberitaan, salah satunya CNN Indonesia menemukan bahwa ada beberapa penjual yang bekerja sama dengan pemegang KJP, dikatakan bahwa pemegang KJP tidak membelanjakan KJP mereka untuk keperluan sekolah melainkan untuk ditukar dengan uang dengan selisih tiga sampai sepuluh persen. (Sumber : CNN Indonesia, dilansir pada 22 Juli 2016)

Sejalan dengan itu, riset ICW (Indonesia Corruption Watch) menemukan sebanyak 19, 4\% penerima kartu Jakarta pintar salah sasaran, dari keseluruhan 405ribu penerima KJP tahun 2013. Jumlah 19,4\% ini berasal dari jenjang peendidikan SD/MI (14,6 \%), SMP/MTs (3.4\%) dan SMA/MA/SMK (1.4 \%). Selain itu ICW menyebutkan bahwa data penerima KJP juga kurang diperbaharui, akibatnya penerima tidak dapat dikonfirmasi atau tidak diketahui keberadaannya.

Sebagai observasi awal peneliti memilih Bank DKI cabang Bendungan Hilir sebagai fakta pendukung observasi, mengingat Bank DKI Bendungan Hilir juga adalah salah satu sarana tempat pengambilan KJP untuk beberapa sekolah khususnya dibeberapa daerah Jakarta pusat, untuk hasil observasi awal peneliti menemukan adanya 
beberapa orang tua peserta didik kategori mampu yang mendapatkan fasilitas Kartu Jakarta Pintar. Hal ini bisa dilihat dari penampilan keseharian, alat elektronik yang digunakan bahkan jenis kendaraan yang dimiliki, yang menurut pengamatan peneliti tidak layak dikategorikan sebagai warga tidak mampu/miskin.

Dari pemaparan di atas, peneliti melihat bahwa adanya perhatian khusus terhadap program KJP dimaksudkan untuk meninjau kembali keefektivan program. Peneliti tertarik untuk megangkatnya menjadi judul skripsi yaitu Efektivitas Program Kartu Jakarta Pintar di SMKN 19 Jakarta. Peneliti melihat adanya indikasi tidak tepat sasaran dan adanya penyalagunaan yang tentunya akan berdampak pada tercapainya tujuan awal program, karena bagaimanapun program Kartu Jakarta Pintar membutuhkan saran dan dukungan dari banyak kalangan untuk perbaikan dan penyempurnaan program itu sendiri.

\section{TINJAUAN PUSTAKA}

\section{Konsep Efektivitas Program}

Efektivitas berasal dari bahasa inggris effective yang berarti berhasil.Sedangkan menurut Kamus Besar Bahasa Indonesia, kata efektiv mempunyai arti efek, pengaruh, akibat atau dapat membawa hasil.Jadi efektivitas adalah keaktivan berarti menunjukan keberhasilan dari segi tercapai atau tidaknya sasaran yang telah ditetapkan, jika hasil semakin mendekati sasaran berarti semakin tinggi efektivitasnya.

Menurut R. Schermerhorn dalam Sefudin (2014) menyatakan An Affective is one that achive high level of task performance member satisfaction and team viability (Efektifitas merupakan satu dari bentuk kepuasan yang tinggi anggota kelompok dan kelangsungan hidup tim). Adapun Menurut Subagyo (2000) efektivitas adalah kesesuaian antar output dengan dengan tujuan yang telah ditetapkan.

Dari beberapa pendapat diatas mengenai efektivitas yang umum menunjukan pada taraf tercapainya hasil, sering atau senantiasa dikaitkan dengan pengertian efisien, meskipun sebenarnya ada perbedaan diantara keduanya. Efektivitas menekankan kepada hasil yang dicapai, sementara efisien lebih menekankan hasil yang dicapai dengan membandingkan antara input dan outputnya.

Menurut Drucker (dalam Nurudin, 2007) menyatakan bahwa effectiveness is to do the right things, while efficiency is to do the things right (efektivitas berarti 
melakukan sesuatu yang benar, sementara efesiensi adalah melakukan sesuatu dengan benar). Atau juga effectiveness how far we achieve the goals and efficiency means how do we mix various resources properly (efektivitas berarti sejauhmana kita mencapai tujuan, sementara efisiensi berarti bagaimana memanfaatkan sumber daya yang ada dengan cermat).

Berkaitan dengan efektivitas dalam program pendidikan, karakteristik program pada umumnya tidak mencari keuntungan. Oleh karena itu pengukuran efektivitas program pendidikan adalah bagaimana program tersebut dapat mencapai tujuan yang telah ditetapkan.

Kata program, berasal dari bahasa inggris yaitu "programe” yang artinya acara atau rencana. Secara konseptual menurut Kamus Besar Bahasa Indonesia (KBBI), program diartikan sebagai suatu asas serata usaha yang akan dijalankan oleh seseorang atau sekelompok tertentu.

Program merupakan sistem. Sedangkan sistem adalah satu kesatuan dari beberapa bagian atau komponen program yang saling kait-mengait dan bekerja sama satu sama lainnya untuk mencapai tujuan yang sudah ditetapkan dalam system. Dengan begitu program terdiri dari komponen-komponen yang saling berkaitan dan saling menunjang dalam rangka mencapai tujuan.

Komponen program adalah bagian-bagian program yang saling terkait dan merupakan faktor-faktor penentu keberhasilan program, karena suatu program merupakan sebuah sistem maka komponen-komponen program dapat dipandang sebagai bagian sistem dan dikenal dengan istilah "subsistem”.

Penilaian efektivitas program perlu dilakukan untuk menemukan informasi sejauhmana manfaat dan dampak yang dtimbulkan oleh program kepada penerimaan program. Hal ini juga menentukan dapat tidaknya suatu program dilanjutkan.

Menurut Gibson (dalam Siswandi 2012:90) untuk mengukur tingkat efektivitas yaitu (1) produksi, merupakan kemampuan organisasi untuk memproduksi jumlah dan mutu output sesuai dengan permintaan lingkungan, (2) efisiensi, merupakan perbandingan (ratio) antara output dan input, (3) kepuasan, merupakan ukuran untuk menunjukan tingkat dimana organisasi dapat memenuhi kebutuhan masyarakat, (4) keunggulan, adalah tingkat dimana keorganisasian dapat dan benar-benar tanggap terhadap perubahan internal dan eksternal, (5) pengembangan, adalah mengukur 
kemampuan organisasi untuk meningkatkan kapasitasnya dalam menghadapi tuntunan masyarakat.

Adapun dalam mengukur dimensi atau kriteria efektivitas menurut Campbell (dalam Sumaryadi, 2005:105) yaitu : "Kualitas, produktivitas, kesiagaan, efisiensi, laba atau penghasilan, pertumbuhan, pemanfaatan, lingkungan, stabilitas, perputaran atau keluar masuknya pekerja, kemangkiran, kecelakaan, semangat kerja, motivasi, kepuasan, penerimaan tujuan organisasi, kepaduan konflik-kompak, keluwesanadaptasi, penilaian dari pihak luar”

Kriteria untuk mengukur efektivitas suatu organisasi ada tiga pendekatan yang dapat digunakan, seperti yang dikatakan Martani dan Lubis (dalam Reski, 2012) yakni:

1. Pendekatan Sumber (resource approach) yakni mengukur efektivitas dari input. Pendekatan mengoptimalkan adanya keberhasilan organisasi untuk memperoleh sumber daya, baik fisik maupun non fisik yang sesuai dengan organisasi.

2. Pendekatan Proses (process approach) adalah untuk melihat sejauh mana efektivitas pelaksanaaan program dari semua kegiatan proses internal atau mekanisme organisasi.

3. Pendekatan sasaran (goals approach) dimana pusat perhatian pada output, mengukur keberhasilan organisasi untuk mencapai hasil (output) yang sesuai dengan rencana.

Arikunto dan Jabar (2008:30) menyebutkan kriteria atau tolak ukur dalam program pendidikan dapat dilihat dari beberapa aspek yaitu (1) peraturan atau ketentuan yang telah diterbitkan, (2) dalam menindaklanjuti ketentuan atau peraturan tersebut perlu adanya petunjuk pelaksanaan (3) jika tidak ada petunjuk pelaksanaaan maka dapat menggunakan konsep atau teori-teori yang terdapat dalam buku-buku ilmiah, (4) atau dapat menggunakan hasil penelitian, (5) kriteria dapat ditentukan menggunakan nalar.

Berdasarkan beberapa kriteria ukuran efektivitas di atas, penulis memilih pendapat Martani dan Lubis (dalam Reski, 2012) hal pendekatan sasaran dimana pusat perhatian efektivitas berada pada outputntya, mengacu dari rencana yang telah dibuat, dalam hal ini penulis memilih mengembalikan ke efektivan program Kartu Jakarta Pintar di SMK N 19 dengan Peraturan Gubernur No 174 tahun 2015. 


\section{Konsep Kartu Jakarta Pintar (KJP)}

Program Kartu Jakarta Pintar (KJP) merupakan program untuk warga yang tidak mampu atau miskin dimana biaya personal pendidikannya di tanggung oleh pemerintah Daerah Provinsi DKI Jakarta (Pergub No. 174 tahun 2015). Program ini merupakan bentuk kebijakan dalam dunia pendidikan yang dikeluarkan oleh pemerintah DKI Jakarta sebagai penyelenggara kebijakan.

Besaran dana rutin yang dapat dibelanjakan setiap bulan untuk tingkatan SD/MI/SDLB adalah Rp. 100.000, untuk SMP/MTs/SMPLB Rp. 150.000 sedangkan untuk SMA/MA/SMK adalah Rp. 200.000. Dana ini hanya bisa dibelanjakan setelah tanggal 10 setiap bulannya dan hanya bisa digunakan pada mesin EDC Bank DKI atau merchant-merchant tertentu yang menggunakan EDC jaringan Prima (BCA).Pada awal ajaran ada tambahan dana sebesar Rp. 500.000 mengingat bannyaknya keperluan siswa di awal ajaran, (Situs resmi KJP :www.kjp.jakarta.go.id dilansir pada 16 juli 2016).

Selain itu, Khusus untuk sekolah swasta terdapat dana tambahan untuk pembayaran SPP, besaran dana maksimal adalah untuk tingkat SD Rp 130.000, SMP Rp. 170.000 dan SMA 290.000 dan SMK Rp. 240.000.

SPP swasta akan di auto debet dari rekening sekolah, jika SPP siswa dibawah alokasi, akan didebet sebesar jumlah SPP ke rekening sekolah, sisanya menjadi hak siswa dan menjadi tabungan siswa. Jika SPP siswa diatas jumlah alokasi, akan di auto debet sebesar jumlah alokasi dan kekurangannya menjadi tanggung jawab siswa.

Tabel 1. Besaran Penerimaan Dana KJP

\begin{tabular}{|l|l|l|l|l|}
\hline \multicolumn{1}{|c|}{ Tingkatan } & \multicolumn{1}{|c|}{$\begin{array}{c}\text { Total Alokasi } \\
\text { Dana Perbulan }\end{array}$} & $\begin{array}{c}\text { Pencairan Dana } \\
\text { Rutin /bulan }\end{array}$ & $\begin{array}{c}\text { Pencairan } \\
\text { dana berkala }\end{array}$ & $\begin{array}{c}\text { Tambahan SPP } \\
\text { untuk Swasta } \\
\text { /bulan }\end{array}$ \\
\hline SD/MI/SDLB & Rp.210.000 & RP. 100.000 & Rp. 660.000 & Rp. 130.000 \\
\hline $\begin{array}{l}\text { SMP/MTs/ } \\
\text { SMPLB }\end{array}$ & Rp. 260.000 & Rp. 150.000 & Rp. 660.000 & Rp. 170.000 \\
\hline $\begin{array}{l}\text { SMA/MA/ } \\
\text { SMALB }\end{array}$ & Rp. 375.000 & Rp. 200.000 & Rp. 750.000 & Rp. 290.000 \\
\hline SMK & Rp. 390.000 & Rp. 200.000 & Rp. 750.000 & Rp. 240.000 \\
\hline
\end{tabular}

(Sumber : Situs resmi KJP www.jakarta.go.id dilansir pada 16 juli 2016) 


\section{Sasaran Program}

Berdasarkan Peraturan Gubernur Nomor 174 tahun 2015 pasal 4 bab 5 disebutkan bahwa sasaran penerima KJP adalah peserta didik dari keluarga tidak mampu atau miskin yang berdomisili dan bersekolah di daerah DKI Jakarta. Peserta didik dari keluarga tidak mampu merupakan peserta didik yang tercatat dalam Pendataan Program Perlindungan Sosial (PPLS). Keluarga tidak mampu adalah rumah tangga dengan tingkat kesejahteraan 40\% terendah di Indonesia, selain hal tersebut keluarga tidak mampu pada Bab Ketentuan Umum Pergub Nomor 174 tahun 2015 dijelaskan pula bahwa keluarga miskin yang dimaksud disini adalah keluarga sangat miskin, hampir miskin dan rentan miskin.

Untuk menentukan apakah sasaran pada program sudah tepat atau belum, maka perlu mengamati program dengan baik, terutama komponen-komponennya, karena yang menjadi sasaran evaluasi bukan program secara keseluruhan tetapi komponen atau bagian program.

Dari beberapa uraian mengenai Peraturan Gubernur terkait masalah KJP diatas, maka penulis dalam hal ini mengambil beberapa point yang akan dijadikan sebagai kriteria sasaran pemenuhan program BPSM bagi siswa penerima KJP dengan tujuan mempermudah dan memperjelas sasaran program KJP itu sendiri, sebagai berikut :

1. Peserta didik merupakan siswa yang tidak pernah terlibat tawuran

2. Peserta didik merupakan siswa dengan daya beli seragam, tas, sepatu yang rendah.

3. Peserta didik merupakan siswa dengan daya beli buku rendah.

4. Peserta didik adalah bukan perokok

5. Peserta didik menggunakan transportasi umum atau tidak memiliki motor.

6. Peserta didik tidak pernah membolos sekolah

7. Peserta didik sebelum menerima KJP adalah siswa dengan daya beli vitamin maupun gizi penunjang tubuh yang rendah.

8. Peserta didik merupakan siswa yang tidak pernah terlibat mencotek massal.

9. Peserta didik bukan pengguna narkotika.

10. 10) Peserta didik membatasi keikutsertaan dalam ekstrakulikuler karna keterbatasan biaya 


\section{Penggunaan Kartu Jakarta Pintar}

Sesuai dengan Pergub No. 174 tahun 2015, bahwa penggunaan KJP meliputi tiga point,sebagai berikut :

1. Bantuan biaya personal pendidikan bagi peserta didik dari kelurga tidak mampu melalui KJP hanya digunakan dan terbatas untuk pembeliaan :

a. Buku tulis

b. Buku gambar

c. Buku pelajaran

d. Alat tulis seperti pensil, pulpen, penghapus, dan rautan

e. Alat gambar seperti macam-macam penggaris, pensil warna, spidol, cat/kertas warna, buku dan /atau kertas gambar dan jangka.

f. Alat dan/ bahan praktis

g. Seragam sekolah dan kelengkaannya

h. Sepatu dan kaos kaki sekolah

i. Tas sekolah

j. Ongkos transportasi dari rumah ke sekolah dan sebaliknya

k. Pakaian olahraga sekolah

l. Buku pelajaran penunjang

m. Kudapan bergizi disekolah

n. Kacamata sebagai alat bantu penglihatan

o. Alat bantu pendengaran

p. Kalkulator scientific

q. USB flash disk sebagai alat simpan data

r. Seragam pramuka dan kelengkapannya dan/atau

s. Pembayaran kegiatan ekstrakurikuler yang tidak dibiayai oleh biaya operasional pendidikan dan bantuan operasional sekolah.

2. Bantuan Biaya Personal Pendidikan bagi peserta didik dari keluarga tidak mampu melalui KJP peserta didik pada satuan pendidikan swasta dan penggunaan sebagaimana dimaksud pada ayat (1) juga dipergunakan untuk membayar sumbangan penyelenggaraan pendidikan. 
3. Rincian penggunaan bantuan Biaya Personal Pendidikan selain dan atau diluar sebagaimana dimaksud pada ayat (1) dan ayat (2) ditetapkan keputusan kepala dinas pendidikan sesuai kebutuhan nyata peseta didik dan perkembangan.

Untuk mencapai efektivitas KJP, maka mekanisme penggunaan KJP ini perlu diatur dengan baik sebagaimana telah dijelaskan diatas.Dalam hal in peranan pemerintah, guru, pedagang dan masyarakat menjadi amat penting. Perlu adanya kerjasama untuk mengawasi penggunaan dari KJP.

Tepat guna, penulis lebih menekankan tentang bagaimana penggunaan KJP sesuai peraturan diatas ataukah tidak, karena tidak dapat dipungkiri bahwa tantangan terbesar dari program KJP adalah tepat penggunaanya. Definisi tepat guna menurut Kamus Besar Bahasa Indonesia berarti daya guna atau efisien.

\section{Larangan dan Sanksi Penyalahgunaan KJP}

Hal-hal yang perlu diperhatikan untuk meningkatkan efektivitas sebuah program adalah pemantauan kerja, berikut beberapa hal yang dilarang bagi peserta didik/ penerima bantuan Biaya Personal Pendidikan melui KJP yaitu :

1. Membelanjakan bantuan Biaya Personal Pendidikan diluar penggunaan yang telah diatur dalam Peraturan Gubernur ini;

2. Merokok;

3. Menggunakan dan mengedarkan narkotika dan obat-obatan terlarang;

4. Melakukan perbuatan asusila/pergaulan bebas/pelecehan seksual;

5. Terlibat dalam kekerasan/bullying;

6. Terlibat tawuran;

7. Terlibat geng motor/geng sekolah;

8. Minum-minuman keras/minuman beralkohol

9. Terlibat pencurian;

10. Melakukan pemalakan/pemerasan/penjambretan;

11. Terlibat perkelahian;

12. Terlibat penipuan;

13. Terlibat nyontek massal

14. Membocorkan soal/kunci jawaban;

15. Terlibat pornoaksi/pornografi; 
16. Menyebarluaskan gambar tidak senonoh baik secara konvensional maupun melalui media online;

17. Membawa senjata tajam dan peralatan lain yang membahayakan;

18. Sering bolos sekolah minimal 4 (empat) kali dalam satu bulan;

19. Sering terlambat tiba disekolah berturut-turut atau tidak berturut-turut minimal 6 (enam) kali dalam 1 (satu) bulan

20. Meminjamkan penggunaan KJP;

21. Menggadaikan / menjaminkan KJP dan/atau buku tabungan dana Bantuan Biaya Personal Pendidikan kepada pihak manapun dan dalam bentuk apapun;

22. Menghabiskan dana bantuan Biaya Personal Pendidikan untuk belanja penggunaan yang tidak secara nyata dibutuhkan oleh peserta didik yang bersangkutan

23. Meminjamkan dana bantuan Biaya Personal pendidikan kepada pihak manapun

24. Melakukan perbuatan yang melanggar peraturan tata tertib sekolah/peraturan sekolah.

\section{METODE}

Dalam penelitian Efektivitas Program Kartu Jakarta Pintar di SMKN 19 ini, peneliti akan menggunakan metode penelitian kualitatif atau deskriptif. Metode kualitatif adalah metode penelitian yang digunakan untuk meneliti kondisi objek yang alamiah, (sebagai lawannya adalah eksperimen), jumlah sampel dalam penelitian ini adalah seluruh siswa/I menerima KJP yaitu sebanyak 50 siswa. Teknik pengumpulan data yang digunakan adalah wawancara dan kuisioner.

\section{PEMBAHASAN}

Rekapitulasi Efektivitas Program Kartu Jakarta Pintar di SMK N 19 Jakarta dapat dilihat pada tabel sebagai berikut:

\begin{tabular}{|c|c|l|c|c|}
\hline No & Indikator & Ruang Lingkup & Persentase & $\begin{array}{c}\text { Nilai } \\
\text { Efektivitas } \\
\text { Rata-rata }\end{array}$ \\
\hline \multirow{2}{*}{1} & $\begin{array}{c}\text { Ketapatan } \\
\text { sasaran }\end{array}$ & $\begin{array}{l}\text { Peserta didik merupakan siswa } \\
\text { yang tidak pernah terlibat } \\
\text { tawuran }\end{array}$ & $100 \%$ & $\begin{array}{c}\text { Efektifitas } \\
\text { Tinggi }\end{array}$ \\
\cline { 3 - 4 } & $\begin{array}{l}\text { peserta didik dengan tempat } \\
\text { tinggal bukan milik sendiri }\end{array}$ & $88 \%$ & \\
\hline
\end{tabular}




\begin{tabular}{|c|c|c|c|c|}
\hline No & Indikator & Ruang Lingkup & Persentase & $\begin{array}{c}\text { Nilai } \\
\text { Efektivitas } \\
\text { Rata-rata }\end{array}$ \\
\hline & & $\begin{array}{l}\text { Tidak Merokok dan atau } \\
\text { mengkonsumi narkoba }\end{array}$ & $100 \%$ & \\
\hline & & $\begin{array}{l}\text { Peserta didik tidak memiliki } \\
\text { motor lebih dari dua }\end{array}$ & $98 \%$ & \\
\hline & & Daya beli vitamin rendah & $84 \%$ & \\
\hline \multirow{5}{*}{2} & \multirow{5}{*}{$\begin{array}{l}\text { Ketepatan } \\
\text { Penggunaan }\end{array}$} & $\begin{array}{l}\text { Digunakan untuk membeli } \\
\text { buku }\end{array}$ & $96 \%$ & \multirow{5}{*}{$\begin{array}{l}\text { Evektifitas } \\
\text { sedang }\end{array}$} \\
\hline & & $\begin{array}{l}\text { Digunakan Untuk Keperluan } \\
\text { Transportasi Umum ke } \\
\text { Sekolah }\end{array}$ & $54 \%$ & \\
\hline & & $\begin{array}{l}\text { Digunakan untuk keperluan } \\
\text { membeli seragam }\end{array}$ & $98 \%$ & \\
\hline & & $\begin{array}{l}\text { Digunakan untuk pembelian } \\
\text { vitamin }\end{array}$ & $84 \%$ & \\
\hline & & $\begin{array}{l}\text { Digunakan untuk keperluan } \\
\text { ekstra Kulikuler }\end{array}$ & $4 \%$ & \\
\hline
\end{tabular}

Tabel di atas menunjukkan bahwa ketepatan sasaran pemberian KJP di SMKN 19 Jakarta sudah efektif, hal ini terlihat dari nilai persentase dari ke empat sangat tinggi, terutama pada indikator ketidakterlibatan siswa dalam tawuran dan indikator tidak merokok serta mengkonsumsi narkoba yang mencapai 100 \%. Hal ini sesuai dengan Larangan penerima KJP yang tertulis dalam Peraturan Gubernur No 174 tahun 2015 salah satunya adalah penerima KJP tidak diperbolehkan merokok.

Berdasarkan hasil wawancara dengan beberapa informan di SMK N 19 di dapatkan:

Informan 1 : "Semua penerima KJP adalah siswa bukan perokok, adapun jika ada siswa tidak mampu tapi merokok maka tidak kami usulkan” (Informan I1, wawancara pada 2 Juni 2017).

Informan 2 mengemukakan bahwa : "Poinnya sih anak-anak penerima KJP sudah tahu diri terhadap larangan tidak boleh merokok maka mereka tidak merokok.adapun dulu memang pernah terjadi ada anak yang kedapatan merokok, maka kami panggil anaknya kami lakukan pembinaan dan pada akhirnya kami cabut hak penerima KJPnya”

Selain ketepatan sasaran dalam pemberian program KJP, ketepatan penggunaan program KJPpun harus sesuai dengan peraturan gubernur. Dari hasil temuan di lapangan didapatkan bahwa evektifitas ketepatan penggunaan KJP masuk kedalam kategori 
sedang. Hal ini ditunjukkan dengan adanya indicator-indikator penggunaan yang masih belum maksimal, misalnya pada indikator penggunaan tranportasi umum untuk menuju ke sekolah hanya mencapai 54 \%. Ini ditunjukkan oleh hampir semua siswa memiliki kendaraan bermotor (satu kendaraan bermotor), sehingga mereka lebih memilih pergi sekolah dengan mengendarai motor ketimbang harus mengguanakan angkutan umum. Hal ini diperkuat oleh Informan 1 dan Informan 2, yang menyatakan bahwa minimnya transportasi yang menggunakan pembayaran dengan KJP itu sendiri.

Penggunaan KJP untuk pembelian barang keperluan ektrakulikuler di SMK N 19 Jakarta tidak efektif yakni mencapai $4 \%$. hal ini patut menjadi perhatian bagi pihak SMK N 19 untuk lebih memaksimalkan penggunaan dana KJP yang lebih diarahkan kepada penggunaan pemanfaatan KJP untuk keperluan ekstakulikuler.

Penggunaan KJP untuk pembelian buku, pembelian seragam, dan pembelian vitamin sudah evektif karena jika dilihat dari persentase penggunaannya sudah mencapai interval nilai 86-98\%.

\section{SIMPULAN}

Penelitian mengenai Efektivitas Program Kartu Jakarta Pintar di SMK N 19 Jakarta disimpulkan sebagai berikut :

1. Indikator ketepatan sasaran program KJP di SMK N 19 menunjukan bahwa semua kriteria sudah tepat dan sangat efektif.

2. Untuk indikator ketepatan penggunaan program, dari 5 kriteria yang ditentukan, 3 kriteria menunjukan sudah efektif yaitu untuk pembelian buku, pembelian seragam dan pembelian vitamin. Adapun untuk kritria pengunaan dana KJP untuk transportasi dan keperluan ekstra kulikuler menunjukan tidak efektif, nilai efektivitasnya masing-masing $54 \%$ dan $4 \%$.

\section{UCAPAN TERIMAKASIH}

Penulis mengucapkan terimakasih kepada Sekolah Menengah Kejuaruan (SMK) N 19 Jakarta dan semua pihak yang telah membantu dalam kelancaran pelaksanaan penelitian. 


\section{DAFTAR PUSTAKA}

\section{Buku:}

Arikunto, S., Safarudin, Abdul Jabar. 2008. Evaluasi Program Pendidikan. Jakarta : Bumi Aksara

Matin. 2014. Manajemen Pembiayaan Pendidikan. Jakarta : PT raja Grafindo Persada

Saefudin, Akhmad, Hendro prasetyo dan Sri hapsari.2014. Perilaku Organisasi. Jakarta : Mitra Abadi.

Siswadi, Edi. 2012, Birokrasi Masa Depan Menuju Tata Kelola Pemerintah Yang Efektif dan Prima, Bandung: Mutiara Press.

Subagyo, Ahmad Wito. 2000. Efektivitas Penanggulangan kemiskinan dalam Pemberdayaan Masyarakat Pedesaan. Yogyakarta : UGM.

Sumaryadi, I Nyoman. 2005. Efektivitras Implementasi kebijakan Otonomi Daerah. Jakarta : Citra Utama

\section{Jurnal:}

Reski. 2012 .Efektivitas Pelayanan perizinan di kantor Pelayanan Perizinan Kabupaten Luwu Timur. Repocitory. unhas.ac.id /bitstream /handle /123456789 /1598/BAB/\%2011.pdf. Diakses pada 5 September 2016

\section{Tesis:}

Nurudin. 2007. Efektivitas pendidikan Gratis Program Pasca Sarjana. Fisip UI.

\section{Peraturan Perundang-Undangan :}

Peraturan Gubernur No 174 tahun 2015 mengenai Bantuan Biaya Personal Pendidikan (BBPP) Bagi Peserta didik Dari Keluarga Tidak Mampu melalui program Kartu Jakarta Pintar

Undang-undang Nomor 20 tahun 2003 tentang sistem pendidikan nasional

\section{Internet:}

Situs resmi KJP. Diakses dari www.kjp.go.id. pada tanggal 16 Juli 2016 pukul 17:00 WIB. 